\title{
What, how, and when for the WHO: will the clock be turned back for the next hematolymphoid tumor classification?
}

\author{
William R. Macon ${ }^{1}$
}

Published online: 19 August 2021

(c) The Author(s), under exclusive licence to Springer-Verlag GmbH Germany, part of Springer Nature 2021

I have been around Hematopathology long enough to remember the controversies produced by having competing classifications of lymphoid neoplasms, which ultimately led to the development of the Working Formulation for Clinical Usage as a means for translating between them [1-3]. The Revised European-American Classification of Lymphoid Neoplasms (REAL Classification), developed by 19 expert hematopathologists collectively known as the International Lymphoma Study Group (ILSG), rescued our subspecialty from the decade-long Working Formulation abyss by defining "real" disease entities [2-4].

The REAL Classification subsequently became the foundation for the third edition of the World Health Organization (WHO) Classification of hematologic malignancies, an arduous task ultimately overseen by a steering committee of seven acclaimed members from the Society of Hematopathology ( $\mathrm{SH})(n=3)$ and the European Association for Haematopathology (EAHP) $(n=4)$ [3, 5]. It involved 11 committee chairs representing both societies, 54 international expert hematopathologists as contributing writers, and a Clinical Advisory Committee (CAC) of 39 international expert hematologists and oncologists $[3,5]$. The completed WHO Classification met the criteria for adoption attributed to Rappaport (clinically useful, scientifically accurate, widely reproducible, easily taught, and readily learned) [6], and it also achieved worldwide consensus for classifying hematopoietic and lymphoid neoplasms. Of note, this endeavor began in 1995 and concluded with its 2001 publication $[3,5]$.

This model was followed successfully for the 4 th and revised 4th editions of the WHO Classification of Tumours of Haematopoietic and Lymphoid Tissues [7, 8], which continued as the single accepted classification scheme. However, for the first time in a quarter century, the next WHO

William R. Macon

macon.william@mayo.edu

1 Mayo Clinic, Rochester, MN, USA
Classification will not be directed by the SH and EAHP since the responsible party, the International Agency for Research on Cancer (IARC), has chosen to go a different direction, presumably in part, because the primary diagnostic method in the WHO Blue Book series as a whole has been histopathology but "other disciplines have an increasingly large role to play" [9]. Furthermore, "the multidimensional nature of cancer classification, the way in which the WHO Classification of Tumours is constructed, and the scientific information overload in the field pose important challenges for the translation of research findings to tumor classification and hence cancer diagnosis." [9]

The 5th edition of the WHO Classification of TumoursHematolymphoid will use a "4-level hierarchical classification, based on cellular ontogeny" [10]. Its framework will be built on the revised 4th edition of the WHO Classification of Tumours of Haematopoietic and Lymphoid Tissues [10] and will be overseen by a subspecialty-independent editorial board of standing members for the entire Blue Book series [11]. The Haematolymphoid Blue Book editorial board will also include 27 international expert members with backgrounds in diagnostic and investigative hematopathology, molecular pathology and cytogenetics, cancer biology, and adult or pediatric hematology/oncology [12]. Some of the Haematolymphoid Experts have been leaders of the SH and EAHP, but none of the former editors or members of the CAC from the 4th edition are included [12]. Therein lies the rub.

In the July 5, 2021, EAHP Newsletter, the respective presidents of the EAHP (Dr. Leticia Quintanilla-Fend) and SH (Dr. Jim Cook) informed the members of each society that the IARC had ended its collaboration with the $\mathrm{SH}$ and EAHP despite protracted negotiations between the Executive Committees (Excos) of the SH and EAHP and IARC [13]. The societies Excos' main objection has been the unilateral IARC process in which a small group of pathologists without input from a CAC produced the aforementioned draft of a classification with a proposed print date of November 
2021 [13]. The reaction has been twofold. First, a significant number of current and past officers and of well-respected members of the SH and EAHP resigned from or declined invitations to join the IARC Expert Editorial Board or to participate as authors for the 5th edition of the WHO Classification of Tumours-Hematolymphoid [13]. Second, there will be a CAC meeting of approximately 120 international pathologists, clinical and scientific experts in September 2021 in Chicago, IL, USA, the conclusions of which will be published in a peer-reviewed journal and possibly form the basis of a new classification [13].

For transparency, I have been invited and have accepted an invitation from the IARC to help author two chapters in the forthcoming Haematolymphoid Blue Book. I accepted this invitation after much thought and with my concluding that since the IARC/WHO train had already left the station, I wanted to help make those chapters in which I am a participant ones that meet the needs of the Hematopathology community. My viewpoint on this matter is not one tainted by my participation in the IARC/WHO Blue Book production but is one from my experiences of the past. I do support having the planned SH/EAHP Excos-endorsed CAC meeting. However, I ask my colleagues participating in that meeting to not embark precipitously on a Societies' sponsored classification of hematolymphoid neoplasms until there has been an opportunity to review the final IARC/WHO product, which will not cause a substantial delay to any actions of the CAC since the Haematolymphoid Blue Book is on the fast track. Be patient and careful, because a different and competing classification that causes loss of global consensus may turn out to be an example of perfection being the enemy of good.

\section{References}

1. Non-Hodgkin's lymphoma pathologic classification project (1982) National Cancer Institute sponsored study of classifications of non-Hodgkin's lymphomas: summary and description of a Working Formulation for Clinical Usage. Cancer 49:2112-2135

2. Berard CW, Hutchison RE (1997) The problem of classifying lymphomas: an orderly prescription for progress. Ann Oncol 8(Suppl 2):S3-S9
3. Harris NL, Jaffe ES, Diebol J, Flandrin, Müller-Hermelink HK, Vardiman J (2000) Lymphoma classification - from controversy to consensus: the R.E.A.L. and WHO Classification of lymphoid neoplasms. Ann Oncol 11(Suppl 1):S3-S10

4. Harris NL, Jaffe ES, Stein H, Banks PM, Chan JK, Cleary ML, Delsol G, De Wolf-Peeters C, Falini B, Gatter KC, Grogan TM, Isaacson PG, Knowles DM, Mason DY, Müller-Hermelink H-K, Pileri SA, Piris MA, Ralfkiær E, Warnke RA (1994) A Revised European-American Classification of Lymphoid Neoplasms: a proposal from the International Lymphoma Study Group. Blood 84:1361-1392

5. Jaffe ES, Harris NL, Stein H, Vardiman JW (Eds) (2001) World Health Organization Classification of Tumours. Pathology and Genetics of Tumours of the Haematopoietic and Lymphoid Tissues. IARC Press: Lyon, France

6. Rappaport H (1977) Roundtable discussion of histopathologic classification. Cancer Treat Rep 61:1037-1048

7. Swerdlow SH, Campo E, Harris NL, Jaffe ES, Pileri SA, Stein H, Thiele J, Vardiman JW (Eds) (2008) WHO Classification of Tumours of Haematopoietic and Lymphoid Tissues. IARC: Lyon, France

8. Swerdlow SH, Campo E, Harris NL, Jaffe ES, Pileri SA, Stein H, Thiele J (eds) (2017) WHO Classification of Tumours of Haematopoietic and Lymphoid Tissues (Revised, 4th edn. Lyon, France, IARC

9. Cree IA, Ruiz BII, Zavadil J, McKay J, Olivier M, Kozlakidis Z, Lazar AJ, Hyde C, Holdenrieder S, Hastings R, Rajpoot N, de la Fouchardiere A, Rous B, Zenklusen JC, Normanno N, Schilsky RL (2021) The International Collaboration for Cancer Classification and Research. Int J Cancer 148:560-571

10. Haematolymphoid (2021) https://whobluebooks.iarc.fr/structures/ haematolymphoid/

11. Editorial Board Standing Members (2021) https://whobluebooks. iarc.fr/editorial-board/standing-members/

12. Editorial Board Expert Members Haematolymphoid Tumours (2021) https://whobluebooks.iarc.fr/editorial-board/expert-membe rs/haematolymphoid-tumours/

13. Quintanilla-Fend L, Cook J (July 5, 2021) Special message from the EAHP and SH - updates and concerns regarding the pending $5^{\text {th }}$ edition WHO Classification. European Association for Haematopathology Newsletter, email communication

Publisher's note Springer Nature remains neutral with regard to jurisdictional claims in published maps and institutional affiliations. 